\title{
NOWA ODSŁONA PODRĘCZNIKA BETER NEDERLANDS DE VERDIEPING GRAMMATICA VOOR ANDERSTALIGEN
}

DOI: http://dx.doi.org/10.18290/rh.2019.67.10-13

Podręcznik Beter Nederlands De verdieping Grammatica voor anderstaligen został wydany w 2018 r. przez wydawnictwo Coutinho i jest wznowieniem wielokrotnie wydawanego podręcznika Beter Nederlands Grammaticaal hulpboek voor anderstaligen. Książkę napisały 4 autorki: Dina Bouman-Noordermeer, Marilene Gathier, Erica Griffioen i Rita Rutten, które zajmują się w praktyce nauczaniem języka niderlandzkiego obcokrajowców w Holandii. Znają więc problemy, z którymi borykają się uczący (się) tego języka. Punktem wyjścia Autorek jest pogląd, że gramatyka nigdy nie stanowi celu samego w sobie, ale pełni rolę wspierającą. Dlatego zgodnie z metodyką nauczania języka obcego prezentują przy każdej konstrukcji gramatycznej jej cel w komunikacji językowej.

Podręcznik składa się ze wstępu, 16 rozdziałów i załącznika z gramatyką występującą w ćwiczeniach. We wstępie Autorki piszą, że książka przeznaczona jest dla osób dorosłych uczących się języka niderlandzkiego zarówno w Holandii, jak i zagranicą, znających język niderlandzki na poziomie B1, czyli dla osób, które dysponują już pewną wiedzą gramatyczną i opanowaniem języka. Zastrzegają jednak, że ich publikacja nie pretenduje do miana podręcznika całościowo opisującego gramatykę języka niderlandzkiego. W 16 rozdziałach zostały opisane zjawiska według nich najważniejsze dla pogłębienia znajomości języka od B1 do B2. Autorki, bazując na praktyce, wybrały te elementy z gramatyki, które stanowią według nich największy problem dla uczących się (zarówno receptywny, jak i produktywny). Podręcznik może stanowić uzupełnienie do obecnych na rynku podręczników tzw. metod, np. Code Plus, Taal Vitaal, Taal Totaal, De Delftse Methode i IJsbreker.

Rozdziały nie stanowią ciągłości. W zasadzie można z nich dowolnie korzystać, co może być atutem, ponieważ kolejność realizowanych treści można dostosować do potrzeb odbiorcy. Jednak z mojego doświadczenia wynika, że istnieją w tym zakresie wyjątki, tzn. najpierw należy zapoznać studentów ze słówkiem er (rozdział 9) a potem przedstawić verwijswoorden met een voorzetsel (rozdział 8).

Podręcznik oferuje krótkie wyjaśnienie danego problemu gramatycznego i ćwiczenia dotyczące tego zjawiska. Na stronie internetowej towarzyszącej podręcznikowi znajdują sie rożne porady dydaktyczne i odpowiedzi do ćwiczeń, jak również dodatkowe informacje teoretyczne pogłębiające wiedzę gramatyczną. Dzięki odpowiedziom nadaje się on do samodzielnej pracy.

W nowym podręczniku znajdują się następujące ważne zagadnienia gramatyczne: użycie różnych czasów, czas perfectum i plusquamperfectum z wieloma

„Roczniki Humanistyczne” 67(2019) z. 10 
czasownikami, strona bierna, czasownik zullen, zdania ze spójnikiem als... dan, spójniki zdań podrzędnie złożonych, zdania podrzędne ze słówkami wskazującymi, słówka wskazujące z przyimkami, słówko er, czasowniki rozdzielnie złożone i zwrotne, czasownik jako określenie rzeczownika, rodzajniki, szczególna grupa czasowników: zien - horen - voelen, czasowniki posiłkowe z te, czasowniki mogen i laten.

W podręczniku Beter Nederlands. De verdieping. Grammatica voor anderstaligen występuje tylko nazewnictwo łacińskie, co może być ułatwieniem dla uczących się języka. Niektóre rozdziały zostały przeredagowane z korzyścią dla nowego wydania (np. rozdz. 3: Strona bierna, rozdz. 5: Als ... dan). Pojawiło się też kilka nowych éwiczeń.

Wszystkie tematy wybrane przez Autorki są moim zdaniem ważne i rzeczywiście stanowią wyzwanie dla studentów. Trudne jest zwłaszcza użycie czasów. Jest to bardzo ważne zagadnienie w języku niderlandzkim, ponieważ ma on inny system czasów niż język polski. W języku polskim istnieje aspekt (większość czasowników występuje w parach dokonany - niedokonany) i są 3 czasy. Język niderlandzki nie zna aspektu wyrażanego morfologicznie i ma 8 czasów, stąd bardzo ważnym ćwiczeniem jest umiejętność właściwego ich stosowania.

Przedstawiany przeze mnie podręcznik bazuje na dwóch już znanych podręcznikach: Beter Nederlands 1 i Beter Nederlands 2 tych samych Autorek. Podręczniki te były wielokrotnie wznawiane, więc trudno oprzeć się chęci ich porównania, zawierają nawet te same rozdziały. Pierwszych 8 rozdziałów omawianego podręcznika to te same 8 , które znajdują się w części 1 Beter $\mathrm{Ne}$ derlands, a kolejne 8 znajduje się w Beter Nederlands 2.

Tytuł nowego podręcznika jest według mnie mylący: Beter Nederlands De verdieping. Ostatnie słowo oznacza 'pogłębienie'. I z tego względu podręcznik przyciąga uwagę. Ale w nowym podręczniku nie ma praktycznie mowy o pogłębieniu. Najpierw w każdym rozdziale znajduje sie krótki opis teoretyczny i zdania przykładowe, wyjaśniające funkcję formy lub struktury gramatycznej, po czym następuje seria ćwiczeń. Zbudowane są one bardzo dobrze, od łatwych ku coraz bardziej kreatywnym, czyli z zachowaniem spiralności stopnia trudności. Ale są to przeważnie te same ćwiczenia, które były umieszczone w poprzednich edycjach. Naniesiono jedynie niewielkie zmiany. Słownictwo jednak jest na tyle neutralne, że nadaje się dla każdego pokolenia.

Przeanalizujmy dla przykładu ćwiczenia z rozdziału pierwszego.

Ćwiczenie pierwsze polega na rozpoznaniu czasów zaprezentowanych w części teoretycznej. Jest to stały typ ćwiczeń - w każdym rozdziale Autorki rozpoczynają pracę nad materiałem teoretycznym ćwiczeniem na rozpoznawanie przedstawianego zjawiska gramatycznego. Ćwiczenie drugie skonstruowane jest na zasadzie 
wyboru, ma trochę większy stopień trudności niż poprzednie. Następne ćwiczenie polega na wyborze jednej z dwóch form czasownika. Kolejne ćwiczenie, zdecydowanie trudniejsze, polega na wstawieniu odpowiedniej formy czasownika w odpowiednim czasie. Student sam musi wybrać, który z czasów zastosować. I ostatnie ćwiczenie to odpowiedzi na pytania, w których osoba ucząca się musi użyć odpowiedniego czasu i poprawnie sformułować zdanie. Wyraźnie widać, że Autorki stopniują trudność. Na koniec umieszczają 3 ćwiczenia utrwalające, które polegają na wstawieniu odpowiedniej formy czasu.

Odpowiedzi do zadań, umieszczone na stronie internetowej, są skąpe - nie podają opisu, dlaczego należy zastosować dany czas, np. perfectum (gdy opisuje się sytuację zakończoną w przeszłości mającą wpływ na teraźniejszość). Taki opis byłby cennym dodatkiem uzupełniającym do odpowiedzi.

Terminy gramatyczne są omówione pobieżnie. Wynika to oczywiście z faktu, że odbiorcą tego podręcznika jest osoba, która chce mówić poprawnie gramatycznie bez zagłębiania się w reguły. Książka jest bardziej praktyczna niż teoretyczna.

Kilka elementów w Beter Nederlands De verdieping wartych jest podkreślenia. Spis treści jest bardziej przejrzysty w porównaniu z poprzednimi wydaniami. Została też zmieniona szata graficzna - kolorem niebieskim zaznaczono nowy materiał i przykładowe zdania w ćwiczeniach.

Natomiast trochę zniechęcić może brak w książce klucza do ćwiczeń. W Holandii chyba wszystkie podręczniki wraz z odpowiedziami dostępne są elektronicznie, dlatego Autorki chciały zapewne iść z duchem czasu. $Z$ jednej strony $\mathrm{w}$ dobie Internetu odpowiedzi $\mathrm{w}$ formie elektronicznej nie stanowią problemu, z drugiej klucz do ćwiczeń stanowiący integralną część z podręcznikiem może być jednak ułatwieniem dla uczących się.

Konkludując, każdy, kto sięgnie po recenzowany podręcznik i wykona zamieszczone w nim ćwiczenia, będzie w stanie budować zdania w języku niderlandzkim na poziomie B2 i jednocześnie poszerzy swoje słownictwo.

Dr Agnieszka Flor-Górecka Katedra Jęzka Niderlandzkiego Katolickiego Uniwersytetu Lubelskiego Jana Pawła II a.flor@kul.lublin.pl 